\title{
What Is the Strategic Role of Online Newspapers?
}

\author{
Arne H. KRUMSVIK
}

\begin{abstract}
The newspapers are in a pressed situation of circulation decline. This is partly a consequence of increased Internet usage, a development the papers themselves have helped push forward. This survey reveals that Norwegian newspapers executives do not approve fully of their own organizations' online activities, and explores their rationale for online publishing: Is it marketing of the print product, the development of new business, or are the newspapers still in an explorative mode?
\end{abstract}

Key Words: newspaper, online newspaper, strategy, Internet, management, economics.

\section{Introduction}

This survey reveals that Norwegian newspapers executives do not approve fully of their own organizations' online activities. In order to understand this lack of satisfaction with their new ventures, it is important to understand their rationale for online publishing: Is it marketing of the print product, the development of new business, or are the newspapers still in an explorative mode? These questions form the center of this article, which outlines the critical developments challenging this industry through the digitalization of news distribution and which explores Norwegian newspaper executives' perceptions of the strategic role of their online newspapers. The discussion of the situation ten years after the occurrence of the online newspaper phenomenon is conducted within the theoretical framework of strategic management, applying Miles and Snow's classic model for the analysis of the strategy, structure and processes of organizations ${ }^{1}$.

\section{From Experiment to Problematic Success': The First Online Newspapers}

News has been online since the 1970s. The first newspaper service on America Online was launched by the Chicago Tribune in May 1992. But not until 1995 was the online newspaper concept of today developed, featuring among others CNN as a global news engine. Six years later, in April 2001, American trade journal Editor \& Publisher Interactive had registered in its database 12,878 news media online (Deuze 2001; Rasmussen 2002:33).

1995 was the year in which public Internet usage had its breakthrough in the entire Western world, largely due to a simpler "point-and-click" interface for the World Wide 
Web. In Norway, Telepost Communications ${ }^{3}$ and Oslonett ${ }^{4}$ provided Internet access to private users, and both had about 10,000 customers by the year's end. The challenge to suppliers of Internet access was the lack of Norwegian content to be used in marketing the new service.

Telepost invited Dagbladet (single copy sales, nationally distributed tabloid) online at a very low cost, to provide attractive content for its own site. The web address testifies to the fact that it might not have been the purpose for users to type the entire URL directly: http://www.telepost.no/dagbl@det.no/.

"Electronic newspapers are so far no serious competition to print papers. But we are on the brink of an information revolution and we want to be part of it", said Dagbladet's Presentation Editor, Ove Monsen, to the business tabloid Dagens Næringsliv ${ }^{5}$.

The Oslo-based subscription newspaper Aftenposten had launched an unofficial test version online, but had it removed in connection with Dagbladet's launch. The slogan "always ahead" ("alltid foran") nevertheless had to be set aside as web-enthusiast and editor of Brønnøysunds Avis, Petter Stephan Krokaa, made sure the five-day local newspaper from the middle of Norway launched its online edition on 6 March 1995, just two days ahead of Dagbladet's heavily advertised online debut.

Krokaa informed Dagens Næringsliv ${ }^{6}$ that the publication at http://www.nordnett.no/ $\sim \mathrm{ba} /$ cost him a mere half hour of work every day, and that the electronic version probably had more readers than the printed issue, which had a circulation of 5,000 copies.

VG (single copy sales, nationally distributed tabloid) brought forth its online edition on 10 October 1995. And even though Dagbladet relaunched a more news-focused issue the day before, it did not keep the country's largest daily from taking the lead online as well. A solid brand and interactive services were its main weapons?

\section{Ten Years of Norwegian Online Newspapers}

Sigurd Høst has kept a register on the development in the number of online newspapers since 1996, and "following a certain amount of hesitation in 1995 (only 17 newspapers registered online by February 1996), a quick expansion came in 1996. Then came three years of relatively slow growth until activities boomed once more in 2000" (Høst 2001:18-19, my translation). This boom was also echoed in media coverage of this new area in the media landscape.

\begin{tabular}{lcc} 
Year & Number of online newspapers* & "Nettavis" in Atekst** \\
\hline 1995 & 17 & 1 \\
1996 & 72 & 87 \\
1997 & 74 & 331 \\
1998 & 102 & 481 \\
1999 & 120 & 511 \\
2000 & 157 & 1456 \\
2001 & 201 & 1775 \\
2002 & - & 1519 \\
2003 & 212 & 1684 \\
2004 & - & 1803
\end{tabular}

*Registration at the end of the year, except 1995, which has registration data from February 1996 (Høst 2004:26).

** Search for "nettavis" (online newspaper) in the Norwegian search database Atekst. 
By the end of 2000, there were 157 newspapers online, and out of these 126 offered a news service as part of its output.

AS Avishuset Dagbladet started the new millennium by establishing DB Medialab AS, a sister company to AS Dagbladet, responsible for its activities in digital media.

As early as 1999, The New York Times had already separated its online activities into a separate company. One of its intentions was to take advantage of the high value estimate and collect external capital to finance further growth ${ }^{8}$.

Separating online activities into separate companies served to make visible its values to the market, increasing the value of the owners' shares. And while print papers were marked by processes of efficiency improvement, the spirit of entrepreneurship was cultivated in new media.

The largest newspaper in Scandinavia, Aftonbladet (single copy sales, nationally distributed Swedish tabloid), also separated its online edition into Aftonbladet Nya Medier AB in 1999, with separate Editor-in-Chief and Managing Director. Shorter decision-making paths enabled the company to develop faster than what had been possible in the mother company.

Dagbladet chose an intermediate solution, with an Editor-in-Chief in common and shared locations for editorial resources. At the same time, increased risk could be taken within a separate corporation.

The trend of separation spread to other major Norwegian newspaper companies, such as VG, Aftenposten and Stavanger Aftenblad (a regional subscription-based newspaper).

Web optimism reached its peak in 2000, followed by a crack at the American NASDAQ stock exchange. The newspapers' competence in downsizing was now made serviceable in their online companies as well. But even though investors got cold feet and advertising income temporarily decreased, it did not halt the growth in online newspaper usage. VG's online edition surpassed the print editions of both Aftenposten and Dagbladet measured by readership in $2004^{9}$. And in 2005 , the online newspaper business received more demand for advertising space than they could offer.

The maturing of the online newspaper market measured by the number of print newspapers with their own respective online editions does not follow a classic diffusion curve, and Sigurd Høst emphasizes two explanatory variables:

If we compare the pattern of diffusion (...) with the ideal-typical S-curve for diffusion (...), it is most notably the fast growth in 1996 which does not fit. Instead of waiting to see what would happen, as many papers did in 1997-1999 (...), many were now anxious to get on early. The explanation is both that they were afraid of being surpassed by the technological development ('being left on the platform as the train leaves'), and that it was possible to create a fairly decent Internet service at a low cost (Høst 2004:14, my translation).

In addition, the launch of Nettavisen.no in 1996 made a significant impact, contributing to changing the market structure.

\section{The Change in the Role as News Provider ${ }^{10}$}

Newspapers were part of a world in which they could pull out the "Exclusive" heading every time they were reasonably certain they were the only ones who covered a specific story or interviewed a specific person. Citations in radio news worked as pure adver- 
tising for the exclusive story, and this interplay continued until the story perhaps was picked up by the evening news on television.

This situation was dramatically changed with the introduction of Nettavisen.no. The entrepreneurs lacked proper funding to launch a new printed paper, and a central part of the business idea was to function as a meta medium in relation to newspapers. By systematically surveying and citing the most interesting stories published in the print media every day, Nettavisen, despite its limited resources and within a short period of time, was able to offer complete news coverage, previously only available through the largest newspapers. On top of that, Nettavisen spiced things up with a few self-produced stories, often quite elegantly developed to make the evening news. In this way, television played the same part in promoting Nettavisen that radio had played in relation to newspapers.

This is where the serious trouble began for the national newspapers. After some time, Nettavisen's breadth constituted a substitute for the omnibus print paper, instead of promoting the original messenger of the particular piece of news. The newspapers responded by increasing efforts in their own online editions and thus reinforced the effect. The news battle was no longer about 24 hours, but about minutes. This was strengthened by the fact that editors publicized the exact time a story was made public. The news competition was given preference over experimenting with new forms of expression and developing the characteristics of the new medium. The new channel was also well suited to news transmission, given its ability to continuously combine the advantages of newspapers, radio and television through the use of multimedia.

In 1995, most newspapers had to ask themselves whether this was in fact a case of cannibalism, but the concerns had to be put aside in favor of looking at the realities of the competition on the market. A year after the birth of online newspapers, the proportions were still so comfortably on the side of the mother publications that the introduction of Nettavisen was perceived as no threat to their financial situation. But as usage of online publications has reached a critical mass, the large media companies have been busy developing their online editions as supplementary products and not substitutes.

VG announced hasty measures when publicizing a drop in circulation in 2004. Feature articles, consumer articles and columns were now to be withheld from online publication or granted exclusivity on paper for a period of time. Dagbladet also announced their policy not to publicize its cover story online, while DN's online edition long had to be content with competing with Nettavisen over citations from its own print sister.

Now, all online papers cite each other, and the problem for print papers that wish to withhold stories from their online editions is that the readers may now find the story in its online rival, and not where it would be logical to start the search. It is precisely the good, exclusive stories that one wishes to withhold. The problem is that these are also the ones that will be cited.

In an attempt to address the dilemma that arises when new media grow from older ones, Dagbladet, at the end of the previous century, announced a strategy to shift attention "from occurrence to context" ("fra hendelse til sammenheng"). The problem of always being ahead on this occasion is that circulation took a fall due to a lower news temperature in the paper edition. And Editor-in-Chief Harald Stanghelle adjusted his rhetoric to: "occurrence and context" ("hendelse og sammenheng"). The newspapers" strong standing online in Norway and Sweden is unique compared to most other markets in the world. The dynamics that followed the launch of Nettavisen, a peculiarly Norwegian phenomenon, is a partial explanation for the situation in Norway. 
It follows that there are few international benchmarks in the search for answers to the questions that arise when the channels are equal in audience reach, but have very different earning capacities.

The exclusive piece of news no longer exists. And at the same time, the newspapers' role as market place is being challenged. The question that newspaper makers have to find an answer to is: What are the qualities and characteristics of newspapers that will have to be developed and emphasized in order to maintain the strong position of the product in the everyday lives of readers?

The days of Nettavisen as an independent outsider are gone after it was acquired by the TV 2 Group and became part of TV 2's website. But all those who dream of a joint effort to charge readers of online newspapers need to reconsider the potential that market players in the free newspapers, such as Swedish Metro, would see in such a situation. In Norway, people are awaiting one of the most digitally sophisticated markets in Europe, according to Jupiter Research ${ }^{11}$. And here there is no paper edition to defend.

To the media corporations, which, according to Dagens Næringsliv's figures in September $2004^{12}$, have invested more than two billion NOK in accumulated online loss, the question is whether they have achieved their goals. Indeed, even more online operations can give rise to operating margins that their mother companies can only dream of, but because the money runs out fast at the other end, the joy over good online figures is only muted.

\section{Theoretical Framework and Methodology}

Companies' adjustments to altered external conditions constitute complex and dynamic processes (Picard 2000, 2003; Kolo, C. \& Vogt, P. 2004). In order to analyze such situations, Miles and Snow developed a model called "the adaptive cycle" (2003:21-28), an attempt to generalize the psychology at work in the behavior of organizations. Three main problems are identified: (1) The entrepreneurial problem (domain definition), (2) The engineering problem (technology), and (3) The administrative problem (structureprocess and innovation).

Figure 1. The Adaptive Cycle

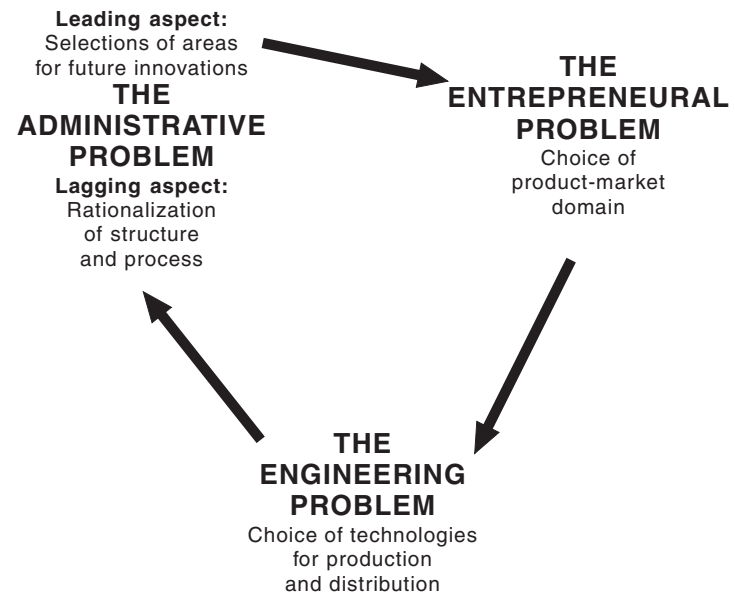


A process of adaptation is likely to work sequentially throughout the three phases, but processes of change may be triggered within all three. However, in the studies conducted by Miles and Snow, it appears that the fastest and most efficient adaptations occur when the right administrative changes are made.

By studying different industries, Miles and Snow identify four archetypes. Each of these has its own strategy in responding to changes in the surroundings, and its typical configuration for technology, structure and process consistent with its strategy. Three stable situations are named "Defender", "Analyzer" and "Prospector", where the company is competitive over time if organized according to its strategic type. The last category is called "Reactor" and represents an unstable situation (Miles \& Snow 2003:29):

1. Defenders are organizations that have narrow product-margin domains. Top managers in this type of organization are highly expert in their organization's limited area of operations, but do not tend to search outside their domain for new opportunities. As a result of this narrow focus, these organizations seldom make major adjustments in their technology, structure or methods of operation. Instead, they devote primary attention to improving the efficiency of their existing operations.

2. Prospectors are organizations that almost continually search for market opportunities, and they regularly experiment with potential responses to emerging environmental trends. Thus, these organizations often are the creators of change and uncertainty to which their competitors must respond. However, because of their strong concern for product and market innovation, these organizations are not completely efficient.

3. Analyzers are organizations that operate in two types of product-market domains, one relatively stable, the other changing. In their stable areas, these organizations operate routinely and efficiently through use of formalized structures and processes. In their more turbulent areas, top managers watch their competitors closely for new ideas, and then they rapidly adopt those ideas that appear to be most promising.

4. Reactors are organizations in which top managers frequently perceive change and uncertainty occurring in their organizational environments but are not able to respond effectively. Because this type of organization lacks a consistent strategy-structure relationship, it seldom makes adjustments of any sort until forced to do so by environmental pressures.

Miles and Snow's model was an important contribution to the development of strategic management as a field of study, founded, inter alias, on the works of Alfred Chandler (1962). Chandler's analyses of large American enterprises documented how changes in strategy are followed by changes in structure. Miles and Snow's contribution has been vital in the formation/development of what is known as "the configurational view of strategy", which explains that there is not an infinite number of alternative routes towards the goal, but rather a handful of fundamental alternatives to choose between in order to achieve what one wants. Porter (1980) is among those who, following the typologies developed by Miles and Snow, has presented his set of generic strategies (cost leadership, differentiation and focus) (Hambrick 2003).

The chosen model of analysis is developed to understand companies within an industry, and it might therefore be problematic to use it in analysis of the newspaper industry at large. In order to deal with this problem, I will attempt to identify some typical traits in this industry and regard newspapers as a player within the total media industry, that is, within a competitive market where different media compete for readers/users and advertisers. 
The core activity of a newspaper company seems basically to correspond to the Defenders category. The focus is on publishing a newspaper, and the top executive is usually an expert on precisely that, besides having worked a long time in the business. The executives do not actively seek opportunities outside of their domain or line of business, and the main focus remains on improving management of the core activity. The large investments that have been made to digitalize the production process seem mostly to be about producing the same thing in a more efficient way.

However, the digitalization of production, storage and distribution of media content paves the way for a new understanding of the line of business within which one operates, and the competition ones partakes in. In this situation, the papers have an advantage because of their rich content and well-established channels for marketing new products and services.

The establishment of online newspapers can be seen as a shift towards the category Analyzer, with operations in one relatively stable part of the market and one rather unstable. In the traditional line of operations the focus is on routine and efficiency, whereas in the new line of business one seeks to adopt good and promising ideas.

Based on historical development and the typology designed by Miles and Snow, a hypothesis of Analyzer as the chosen main strategy would seem to be a reasonable supposition. The structure and processes of the organization are differentiated in order to account for both stable and dynamic spheres of activity. Hence, the survey is designed to give a preliminary assessment of such a hypothesis. First of all, it is vital to discover (1) whether executives see use of the Internet mainly as an opportunity for their organization, and (2) what the functions of online priorities are in the company's strategy to make use of new opportunities. Also, to fit in a stable situation as Analyzer, (3) a clear formulation of the strategy and the necessary adjustment of structure and processes are decisive.

The survey was conducted in April 2005 in cooperation with Landslaget for Lokalaviser (LLA) and Mediebedriftenes Landsforening (MBL). 193 executives (editors, managing directors and publishers) in Norwegian print papers have responded to 24 questions in an e-mail/web-based questionnaire ${ }^{13}$. The response rate was 68 per cent, after two rounds of e-mail reminders. The results are presented in the following section.

\section{The Results}

When Norwegian newspaper executives are asked whether they perceive use of the Internet as a threat or an opportunity, they are more optimistic with regard to their own paper than when asked about the newspaper business in general.
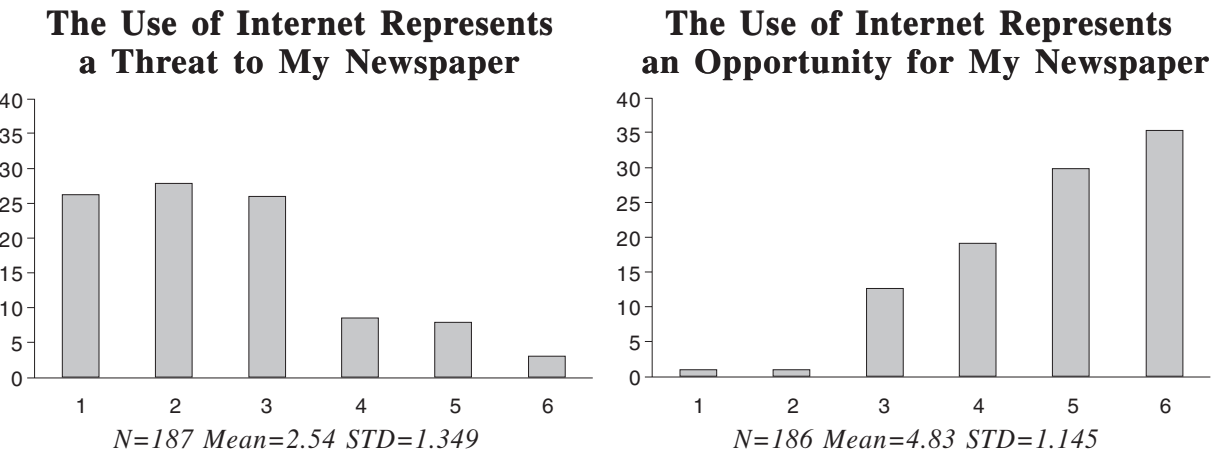
The Use of Internet Represents

a Threat to My Newspaper

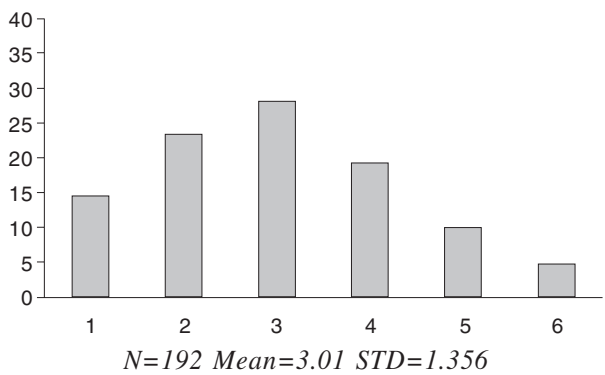

The Use of Internet Represents an Opportunity for My Newspaper

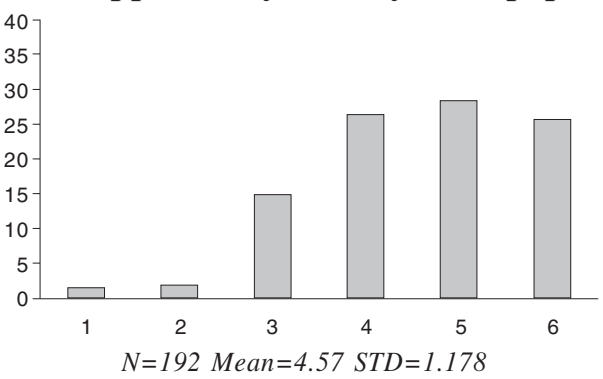

$1=$ totally disagree. $6=$ totally agree

There are no significant differences between papers of different sizes in their view on the use of Internet in relation to their own operations.

Newspaper executives largely seek to use online newspapers to defend the print edition's existing market position.

\section{What are the Functions of the Newspaper's Online Edition? ${ }^{14}$}

1. Part of a strategy to provide readers and advertisers with a service in more channels $(67 \%)$

2. Marketing the print paper $(62 \%)$

3. Defending the market position among readers and advertisers (59\%)

4. Providing the paper/company with a contemporary image $(52 \%)$

5. Using content from print edition in new channels $(47 \%)$

6. Providing the company with new revenue sources (40\%)

7. Exploring new opportunities in new media (31\%)

\section{Which Function Is the Most Important to the Online Edition?}

1. Part of a strategy to provide readers and advertisers with a service in more channels $(30 \%)$

2. Defending the market position among readers and advertisers (23\%)

3. Marketing the print paper (12\%)

4. Providing the paper/company with a contemporary image $(8 \%)$

5. Using content from the print edition in new channels (5\%)

6. Providing the company with new revenue sources $(5 \%)$

7. Exploring new opportunities in new media (3\%)

Young readers are the most important target group.

Which Target Group Is the Most Important to the Paper's Online Edition?*

1. Young readers $(51 \%)$

2. New readers $(40 \%)$

3. New advertisers (27\%)

4. Existing readers (11\%)

5. Existing advertisers (11\%)

6. Elderly readers $(5 \%)$

$*=$ the percentage that considers this target group to be especially important. Multiple answers permitted.

Top executives are only partly satisfied with the online operations of the newspaper. Most of them feel the online papers should charge users. 
All in All, How Satisfied Are You with the Newspaper's Online Activities Today?

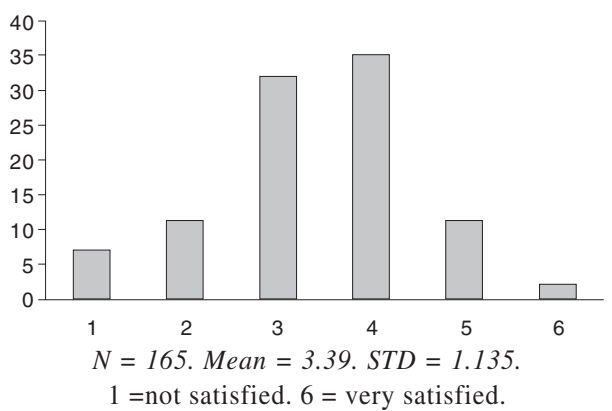

Online Newspapers Should Charge Their Users

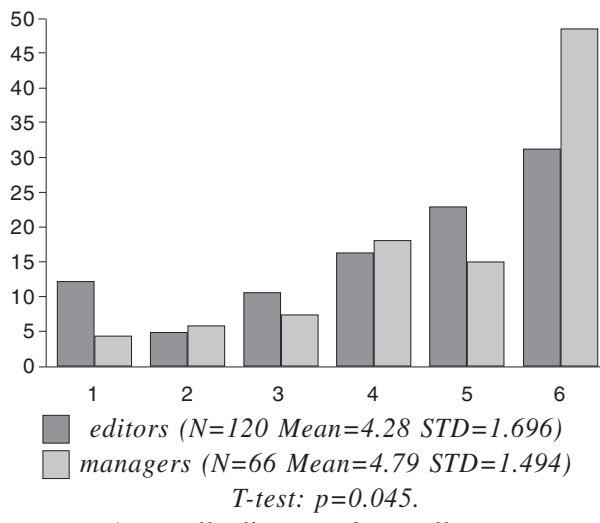

$1=$ totally disagree. $6=$ totally agree.

Executives of the largest newspaper (circulation 40,000+) are more satisfied with their online operations than executives of small newspapers (circulation up to 10,000).

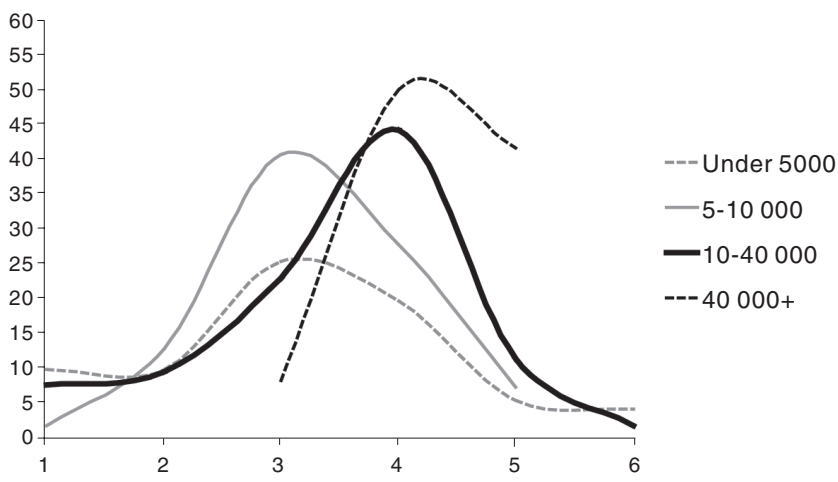

\section{Descriptives}

Alt i alt, hvor fornøyd er du med avisens nettaktiviteter i dag? ( $1=$ lite fornøyd, $6=$ =svært godt fornøyd)

\begin{tabular}{|c|c|c|c|c|c|c|c|c|}
\hline & \multirow[b]{2}{*}{$\mathrm{N}$} & \multirow[b]{2}{*}{ Mean } & \multirow[b]{2}{*}{$\begin{array}{c}\text { Std. } \\
\text { Deviation }\end{array}$} & \multirow[b]{2}{*}{$\begin{array}{l}\text { Std. } \\
\text { Error }\end{array}$} & \multicolumn{2}{|c|}{$\begin{array}{l}95 \% \text { Confidence } \\
\text { Interval for Mean }\end{array}$} & \multirow[b]{2}{*}{$\begin{array}{l}\text { Mini- } \\
\text { mum }\end{array}$} & \multirow[b]{2}{*}{$\begin{array}{l}\text { Maxi- } \\
\text { mum }\end{array}$} \\
\hline & & & & & $\begin{array}{l}\text { Lower } \\
\text { Bound }\end{array}$ & $\begin{array}{l}\text { Upper } \\
\text { Bound }\end{array}$ & & \\
\hline Under 5000 & 53 & 3,19 & 1,316 & 181 & 2,83 & 3,55 & 1 & 6 \\
\hline $5000-10000$ & 49 & 3,29 & ,890 & ,127 & 3,03 & 3,54 & 1 & 5 \\
\hline $10000-40000$ & 51 & 3,49 & 1,138 & 159 & 3,17 & 3,81 & 1 & 6 \\
\hline Over 40000 & 12 & 4,33 &, 651 & , 188 & 3,92 & 4,75 & 3 & 5 \\
\hline Total & 165 & 3,39 & 1,135 & ,088 & 3,22 & 3,57 & 1 & 6 \\
\hline
\end{tabular}




\section{Multiple Comparisons}

Alt i alt, hvor fornøyd er du med avisens nettaktiviteter i dag?

(1=lite fornøyd, $6=$ =svært godt fornøyd)

\begin{tabular}{|c|c|c|c|c|c|c|}
\hline \multirow[b]{2}{*}{ (I) Opplag: } & \multirow[b]{2}{*}{ (J) Oppplag: } & \multirow{2}{*}{$\begin{array}{c}\text { Mean } \\
\text { Difference } \\
(I-J)\end{array}$} & \multirow[b]{2}{*}{ Std. Error } & \multirow[b]{2}{*}{ Sig. } & \multicolumn{2}{|c|}{ 95\% Confidence Interval } \\
\hline & & & & & Lower Bound & Upper Bound \\
\hline \multirow[t]{3}{*}{ Under 5000} & $5000-10000$ &,- 097 & 220 & 1,000 &,- 68 & ,49 \\
\hline & $10000-40000$ &,- 302 & ,217 & 1,000 &,- 88 & ,28 \\
\hline & Over 40000 & $-1,145^{*}$ & ,354 &, 009 & $-2,09$ &,- 20 \\
\hline \multirow[t]{3}{*}{$5000-10000$} & Under 5000 &, 097 & ,220 & 1,000 &,- 49 & ,68 \\
\hline & $10000-40000$ &,- 204 & ,222 & 1,000 &,- 80 & ,39 \\
\hline & Over 40000 & $-1,048$ & ,357 & ,023 & $-2,00$ &,- 09 \\
\hline \multirow[t]{3}{*}{$10000-40000$} & Under 5000 & ,302 & ,217 & 1,000 &,- 28 & ,88 \\
\hline & $5000-10000$ & ,204 & ,222 & 1,000 &,- 39 & ,80 \\
\hline & Over 40000 &,- 843 & ,355 &, 113 & $-1,79$ &, 11 \\
\hline \multirow[t]{3}{*}{ Over 40000} & Under 5000 & $1,145^{*}$ & ,354 &, 009 & ,20 & 2,09 \\
\hline & $5000-10000$ & 1,048 & ,357 & ,023 & ,09 & 2,00 \\
\hline & $10000-40000$ & ,843 & ,355 & ,113 &,- 11 & 1,79 \\
\hline
\end{tabular}

Variable: All in all, how satisfied are you with the newspaper's online activities today?

\section{Discussion}

Arguably, the newspapers perceive the use of the Internet as an opportunity, but it is not quite as clear whether they want to take this opportunity and use it to develop new business areas, or primarily to recruit new readers to the print edition.

An important indicator is that only $5 \%$ of the top executives respond that the primary role of the online commitment is to provide the company with new revenue sources, even though $40 \%$ see this as a secondary goal. But both as main and partial role, this factor is sixth and second to last in the ranking.

This may indicate that the role as Defender still has a strong hold in the newspaper organizations. Business development in this branch is often done at the corporate level or by constructing local superstructures in the forms of media houses where newspaper, local radio and local television are sister activities in a strategy to keep intruders off the dominant position that local newspapers have managed to establish in the advertising market. This is enhanced by advertising networks that enable them to compete on the national and regional market as well, and if necessary by establishing free newspapers to produce reach or prevent new start ups.

With a historical background such as this, it might not come as a surprise that online activities are largely considered a defensive strategy. Almost half of the respondents use the online editions primarily for the purpose of "defending the market position among readers and advertisers" (23\%), "marketing the print paper $(12 \%)$, or "providing the paper/company with a contemporary image" (8\%).

Seen in relation to the results of the multiple-choice option, a clear image is forming of online editions as having many different and partly contradictory roles at the same time, thereby increasing the complexity when strategies are to be operationalized. The clear desire to be able to charge users is contrasted to the desire to use the Internet to recruit young target groups for the print paper. 
This lack of clarity is, however, not new. "Fear, uncertainty and doubt" were, according to New York Times columnist Denise Caruso, the most important driving forces for the newspaper business when they plunged into the online adventure without established business models to which to refer. In an article in the Columbia Journalism Review in 1997, she congratulated the Silicon Valley strategists in succeeding in creating an image of reality in which media companies worldwide saw the need to hurl themselves onto a train which was about to leave the platform.

"Show me the money!" was her provocative title, making a reference to another contemporary cultural expression from Southern California (Caruso 1997). Now, increasing numbers of large newspapers can show that they make good money on online activities, but insecurity still marks the business.

A probable partial explanation for this is that circulation figures for print papers are a source of stress. In Norway, the total newspaper circulation has been down six years in a row, and nothing suggests that this decline will turn.

This may indicate that many papers, both today and ten years ago, act in a way that may fall into the Reactors category. When top executives are only partly content with online activities, this may suggest that the formula is yet to be found and that the balance between traditional and new activities in an Analyzer model has not been established in a satisfactory way.

Miles and Snow (2003:93) identify three main reasons why an organization acts as Reactor:

1. Top management may not have clearly articulated the organization's strategy.

2. Management does not fully shape the organization's structure and processes to fit a chosen strategy.

3. There is a tendency for management to maintain the organization's strategy-structure relationship despite overwhelming changes in environmental conditions.

Top executives at the largest newspapers are more content with the situation, and a characteristic corroborating this is that they have taken structural moves to develop an Analyzer approach. The approach is realized by establishing separate daughter or sister companies to run and develop new media activities. At the previous turn of the century, some of these new companies had ambitions to go in the direction of Prospectors, but despite several attempts, it turned out to be the related online newspaper concept that received attention. In this sense, these companies also represent the mere partial establishment of an Analyzer position for the activities of the media house.

It is also necessary to problematize the role of journalism in a media channel that, in the opinion of many respondents, has the purpose of promoting the print paper (main function: $12 \%$, partial function $62 \%$ ), or providing the paper/company with a contemporary image (main function: $12 \%$, partial function $52 \%$ ). Is there room for original critical and investigative journalism in such a context, or is this to be considered advertising?

This survey represents a pre-analysis of this market, and additional research will further explore these circumstances by investigating individual companies' choices of structure and processes. 


\section{Conclusion}

The newspapers are in a pressed situation of circulation decline. This is partly a consequence of increased Internet usage, a development the papers themselves have helped push forward. Thus, they have influenced their environment in such a way as to challenge their own core activity, while at the same time being well positioned in new media. However, they have not succeeded in finding a balanced focus between traditional and new activities. It seems as though newspaper executives find it hard to respond efficiently to the insecurity created as a result of changes in the environment.

It is still not clear what may be the answer to the question: "What kind of strategic role do the online newspapers play?" Even though only 3 per cent answer that "exploring new opportunities in new media" is the primary function ${ }^{15}$ of the online newspaper, it nevertheless seems as though that description may best summarize the situation of many players after ten years. Fear, uncertainty and doubt are still part of the newspaper business.

\section{Notes}

1. Raymond E. Miles and Charles C. Snow initially published the book Organizational Strategy, Structure, and Process in 1978 through McGraw-Hill, New York. Twenty-five years later, it was republished in the series "Stanford Business Classics" by Stanford University Press.

2. The background overview is based on Krumsvik, Ottosen and Steensen: "Et historisk perspektiv på nettavispublisering og dens konsekvenser for endring av journalistrollen og redaksjonelle prosesser $\mathrm{i}$ en digital medieutviklling" (A historical perspective on online newspaper publishing and its repercussions on changing the role of the journalist and editorial processes in the development of digital media), paper presented at the KML Conference at Jæktvollen, Norway 25-26. May 2005.

3. A joint venture between Telenor and Posten.

4. Internet start up established in the Informatics Building at the University of Oslo 12th December 1991, and purchased by Schibsted-gruppen 1st November 1995. Changed its name to Schibsted Nett.

5. Dagens Naringsliv 9 March 1995: "Elektronisk Dagblad var først - igjen"

6. Dagens Naringsliv 14 March 1995: "Dagbladet ikke først"

7. Dagens Naringsliv 9 October 1995: "Papirløs tabloid"

8. Medieverden nr. 29/1999: "Nettaviser går sine egne veier" (Online newspapers going their own ways) and nr. 9/2001: "Nettavis-fokus på bunnlinjen" (Online newspapers focusing the bottom line).

9. TNS Gallup "Mediebarometer" 2004

10. Excerpts from the articles "Eksklusiv umulighet" (Exclusive impossibility) 11.03 .05 and "Ferdig med eksperimentene" (Done with experimenting) 14.04.05 in Dagens Næringsliv.

11. Jupiter Research: 'European Digital Life Index, 2005” EUH05-C01.

12. Dagens Naringsliv 11. September 2004: "Nett vest"

13. The survey was conducted using the software tool Questback and analyzed using SPSS 12.0.1 for Windows.

14. The alternatives are developed based on the reasons given by participants throughout the ten-year-long duration of the online newspapers' existence, recorded from my own experience from managerial positions in the period 1995-2001 (VG Online: Project Manager, Schibsted Nett: Editor, Scandinavia Online: Managing Editor, Dagbladet.no: Editor and Manager, DB Medialab: Publisher and CEO) and then as corporate strategist (A-pressen and TV 2 Group) and observer - with a few guest appearances as a consultant.

15. $30 \%$ mention this as a partial function, but it is still the least important.

\section{References}

Caruso, D. (1997) Show me the Money! How the FUD Factor has Online News in its Thrall. New York: Columbia Journalism Review July/August 1997.

Chandler, A.D. Jr. (1962) Strategy and Structure: Chapters in the History of the American Industrial Enterprise. Cambridge: The MIT Press. Chyi, Hsiang Iris and Lasorsa, Dominic L. (2002) 'An 
Explorative Study on the Market Relation Between Online and Print Newspapers', Jounal of Media Economics. 15(2002)2, Mahwah, NJ: Lawrence Erlbaum Associates, 91-106.

Deuze, M. (2001) Online Journalism: Modelling the First Generation of News Media on the World Wide Web. First Monday, 6(2001)10 (October).

Hair, J., Anderson, R., Tatham, R., and Black, W. (1998) Multivariate Data Analysis (5 ${ }^{\text {th }}$ ed.) Prentice Hall.

Hambrick, D. (2003) 'Foreword to the Classic Edition', in Miles, R. and Snow, C. (2003) Organizational Strategy, Structure, and Process. Stanford Business Classics. Stanford University Press.

Høst, S. (2000) Avisåret 1999 - Nye gratisaviser, flere aviser på Internett. Rapport 2/2000. Fredrikstad: Institutt for Journalistikk.

Høst, S. (2004) Avisåret 2003 - Farvel til fullformatet? Revidert utgave. Rapport 2/2004. Fredrikstad: Institutt for Journalistikk.

Kolo, C. and Vogt, P. (2004) Traditional Media and Their Internet Spin-Offs: An Explorative Study on Key Levers for Online Success and the Impact of Offline Reach, St. Gallen: The International Journal on Media Management, 6(2004)1\&2.

Miles, R. and Snow, C. (2003) Organizational Strategy, Structure, and Process. Stanford business classics. Stanford University Press. [Originally Published in 1978. New York: McGraw-Hill]

Picard, R. (2003) Cash Cows or Entrecôte: Publishing Companies and Disruptive Technologies. Trends in Communication; 11(2003)2, p.127.

Picard, R. (2000) Changing Business Models of Online Content Services - Their Implications for Multimedia and Other Content Producers. St. Gallen: The International Journal on Media Management, 2(2000)2, 60-68.

Porter, M. (1980) Competitive Strategy: Techniques for Analyzing Industries and Competitors. New York: The Free Press.

Rasmussen, T. (2002) Nettmedier. Journalistikk og medier på Internett. Bergen:Fagbokforlaget. 